This is a self-archived version of an original article. This version may differ from the original in pagination and typographic details.

Author(s): Riivari, Elina; Malin, Virpi; Jääskelä, Päivikki; Lukkari, Teija

Title: University as a workplace : searching for meaningful work

Year: 2020

Version: Accepted version (Final draft)

Copyright: @ 2018 Informa UK Limited, trading as Taylor \& Francis Group

Rights: In Copyright

Rights url: http://rightsstatements.org/page/InC/1.0/?language=en

Please cite the original version:

Riivari, E., Malin, V., Jääskelä, P., \& Lukkari, T. (2020). University as a workplace : searching for meaningful work. Teaching in Higher Education, 25(3), 286-304.

https://doi.org/10.1080/13562517.2018.1563061 


\section{University as a Workplace: Searching for Meaningful Work}

Elina Riivari*

University of Jyväskylä, School of Business and Economics

Agora, P.O. Box 35, FI-40014 University of Jyväskylä, FINLAND

tel. +358407581258

e-mail: elina.riivari@jyu.fi

ORCID: 0000-0002-8923-6452

Virpi Malin

University of Jyväskylä, School of Business and Economics

Agora, P.O. Box 35, FI-40014 University of Jyväskylä, FINLAND

tel. +358408054624

email: virpi.malin@jyu.fi

ORCID: 0000-0002-0927-568X

Päivikki Jääskelä

University of Jyväskylä, Finnish Institute for Educational Research

P.O. Box 35, FI-40014 University of Jyväskylä, FINLAND

tel. +358408053333

email: paivikki.jaaskela@jyu.fi

ORCID: 0000-0002-3794-0325

Teija Lukkari

University of Jyväskylä, Language Centre

P.O. Box 35, FI-40014 University of Jyväskylä, FINLAND

tel. +358408053154

email: teija.lukkari@jyu.fi

*Corresponding author 


\title{
University as a Workplace: Searching for Meaningful Work
}

\begin{abstract}
Work in academia is changing, and research suggests that not all the changes are desirable. Higher education is developing in a direction heavily criticised, especially in relation to the concepts of neoliberal and academic capitalism. In this article, we explore meaningful work in a university context. Our focus lies on individual lecturers' positive opportunities to make work meaningful and the university a better place to work for both students and faculty. We examine meaningful work as a relational phenomenon: how meaningfulness is constructed through features such as dialogue, expertise, interaction and sharing of ideas. Our empirical findings are based on analysis of qualitative and quantitative data collected in a business school management course deliberately developed to promote cooperation, interaction and shared learning as central tenets of meaningful work. Both faculty members' and students' perspectives on meaningful work are discussed.
\end{abstract}

Keywords: Meaningful work; higher education; good organization; dialogue; cooperation

Word count: 7006 words (excluding references) 


\section{University as a workplace: Searching for meaningful work}

\section{Introduction}

Several indicators show that work in academia is changing, and research suggests that not all the changes are desirable or good. Contemporary higher education is developing in a heavily criticised direction, especially in relation to the concepts of neoliberal and academic capitalism (e.g. Alajoutsijärvi, Juusola and Siltaoja 2013; Cantwell and Kauppinen 2014; Fotaki and Prasad 2015; Kenny 2017). However, at the same time, theories on good organisations and good work are gaining increasing interest among researchers. One concept recently used to describe both good working conditions and subjective involvement is meaningful work.

Research on meaningful work has mainly been conducted in the organizational studies field and concentrated on views on the worker and work itself, highlighting work values, work involvement, salience, centrality, work orientation, job crafting and job design as important topics (Michaelson et al. 2014). However, in these studies, work and the worker connotes wage work. Yet, many of the elements related to meaningfulness - engagement, agency, personal growth, identity work, purpose, freedom, autonomy and control - can be regarded as important in any kind of objective-oriented action. Studying - as 'the work of students' (Wardley, Bélanger and Nadeau 2016) - is an example of objective-oriented work that encompasses these elements.

The university is a unique workplace as it is a working place not only for employees but also for students. We, therefore, claim that both faculty members' and students' perspectives on meaningful work are equally important when trying to understand the concept of meaningful work in a university context. From an educational perspective, they are like the horse and the carriage - 'you can't have one without the other'.

This study contributes to the idea of meaningful work in a university context. In this paper, we empirically examine the concept of meaningful work in the case of a management 
course at a business school. What makes this course special is its emphasis on cooperation, interaction and shared learning, which are all essential elements of meaningful work. These aspects have been noted in every phase of the course and teaching methods have been chosen to support them. The course follows an interactive format including individual and group work in multidisciplinary groups and students' peer evaluation. The course is continuously planned, taught and developed by three lecturers coming from different units at the university. All these aspects and features of the course aim to improve lives in the academia: both the lives of faculty members and the lives of students as current student workers and future specialists and managers.

In order to further conceptualize the concept of meaningful work, we apply Erik Allardt's (1993) sociological theory of welfare. In Nordic languages, the word welfare (välfärd in Swedish, velferd in Norwegian, velferd in Danish and hyvinvointi in Finnish) also denotes well-being and is associated with level of living, as well as quality of life (Allardt 1993). Allardt's (1993) model of having, loving and being forms the framework for both theoretical and practical illustrations of meaningful work in the case explored.

\section{Meaningful work}

According to Ciulla (2015), meaningful work describes work that is worthwhile, significant, satisfying and conducive to personal growth, self-efficacy, self-esteem, belongingness and well-being. Yeoman (2014) defines meaningful work from the perspective of human needs, emphasizing the role of freedom, autonomy and dignity. Despite similar conceptual interests among researchers, there arguably is no universal agreement on what constitutes meaningful work (Michaelson et al. 2014, 81). While definitions of meaningful work vary within the organizational studies field, the topic is generally acknowledged (Lepisto and Pratt 2017), and some scholars even find it to be 'one of the most important questions for organizational 
scholarship' (Podolny, Khurana and Hill-Popper 2005, 1). To summarize, meaningful work focuses on the reasons that justify the worthiness of work, and the research on meaningful work is ultimately about the question: 'Why is my work worth doing?' (see Lepisto and Pratt 2017). The very same question is highly relevant from students' perspective. Conceptually, worthiness of work relates to the multidimensional phenomenon of student agency, which highlights the interdependence of subjectivity (subjects' thinking, sense and experiences) and socio-cultural contexts in human action and development (e.g. Jääskelä et al. 2017a).

Organizational research indicates that meaningful work is positively associated with employee outcomes (Michaelson et al. 2014), such as improved job performance (Fried and Ferris 1987; Grant 2008), job satisfaction (Wrzesniewski et al. 1997), engagement (May, Gilson and Harter 2004) and well-being (Soane et al. 2013). Organizational commitment and occupational identification (Bunderson and Thompson 2009; Liden, Wayne and Sparrowe 2000) have also been identified as outcomes of meaningful work (Michaelson et al. 2014). Currently, organizational research is interested in the factors that enhance meaningful work, including job design, interpersonal relationships and organizational cultures (Ashforth 2003; Michaelson et al. 2014; Pratt and Ashforth 2003; Rosso, Dekas and Wrzesniewski 2010). Research on student satisfaction (Griffioen, Doppenberg and Oostdam 2018), student identity development (Bennett 2012) and design of students' work (Wardley, Bélanger and Nadeau 2017) has reported similarly positive outcomes from students' perspectives.

Meaningfulness is positively related to employees' self-identity, institutional citizenship and resilience against burnout (Mitra and Buzzanell 2017). It has been stated that meaningful work is valued more than wealth or happiness (King and Napa 1998), and for young employees, the absence of meaningfulness is a key reason for changing workplaces (Lancaster and Stillman 2010,86). In the university context, however, changing workplaces is not an easy option, and for many researcher work may still feel meaningful even if other duties such as 
teaching and supervising may not. In this sense, incentives, as discussed later, act as driving forces. From students' perspective, changing 'workplaces' is even more unfeasible, so the lack of meaningfulness may be demotivating, appear to be performing instead of learning, and even lead to dropouts. Of course, students may transfer to different majors or degrees, but this option typically requires a formal application process and offers no certainty of acceptance. The elements of meaningful work as described in this study do necessarily appear in any given course. If a course is required within a study module in a student's a major or minor, 'changing the workplace' is even impossible.

In the field of organization studies, meaningful work has been examined from two main perspectives. First, a stream of research is interested in work that is meaningful, in other words, purposeful and significant for individuals (Pratt and Ashforth 2003; Rosso, Dekas and Wrzesniewski 2010). Second, meaningfulness is typically viewed as a function of the fit between the employee and the tasks or the work itself: meaningful work fulfils the employee's needs or aligns with the employee's values and beliefs (Michaelson et al. 2014). Organizational researchers have focused more on employees' experiences, while business ethicists have paid attention to the moral obligations of employing organizations (Michaelson et al. 2014). Organizational scholars typically start from the assumption that meaningful work is a positive thing, while ethicists try to find a philosophical basis for why it is positive (Michaelson et al. 2014).

Business ethicists have paid attention to the features of meaningful work in which employees have moral rights, such as autonomy, fair compensation and treatment, professional development (Bowie 1998; Schwartz 1982), opportunities to influence and the right to participate (Hsieh 2008). It is hard to imagine that these features would not equally apply to the work of students. The difficult question that arises then is how to design educational work so that both students and faculty members find their work to be meaningful. 


\section{Critical perspectives on meaningful work}

In addition to research concentrating on the positive outcomes of meaningful work, there are other studies that indicate 'the dark side' of the concept. In their recent work, Mitra and Buzzanell (2017) discuss the communicative tensions of meaningful work and examine meaningfulness as a dynamic and contested negotiation. The authors criticize the tendency to view meaningful work as primarily positive and indicate how meaningfulness stems from a variety of organizational, professional and political structures (Mitra and Buzzanell 2017).

It should also be noted that the question of meaningful work is undoubtedly also bound to culture. According to Michaelson et al. $(2014,87)$, most of the research conducted has focused on North American and Western European workers or advanced economies. As the discussion on meaningful work clearly shows, the main interest lies in individuals and their attitudes and perceptions. From the organizational perspective, the interest in meaningful working conditions can be said to be based on subjective elements. It can be argued that the Western discussion is mostly individualistic in nature and based on Western values and philosophies, such as Bowie's (1998) Kantian theory of meaningful work. Questions about meaningful work and worker identity appear completely different in collective cultures, where

individual identity depends on being a member of the collective. The whole question of meaningful work becomes quite different in communities in developing countries where work, often in poor conditions, is merely a means to survival.

Cultural differences, however, do not appear only between individual and collective cultures and between developed and developing countries. In academia, cultural differences between universities appear in many forms that can be political, national or even regional in nature. Power distance is a good example of these cultural differences. Students in universities that operate according to conservative values of high level of hierarchy, control and governance 
might not even think that their work could be more meaningful based on the aforementioned moral rights. Addressing the question of meaningful work in the university context, therefore, demands taking into account culture-specific features.

The concept of cognitive capitalism has been discussed when referring to controlling and governing human knowledge in the name of performativity and productivity. Performativity, a crucial element in neoliberalist ideology, links individual experiences and identities to institutional practices, norms and governance. Performativity becomes a state of mind when we internalize others' expectations. In academia, this has become evident in the taken-for-granted presumption that certain rankings, evaluations and comparisons demonstrate excellence. Ball (2003) points out a contradiction between the first-order activities demanded by performativity and the second-order activities of work performance monitoring and management. Ball (2003) claims that performativity requirements consume so much energy that they reduce possibilities for development input. According to this critique, engagement through meaningful work only refers to novel ways of exploitation in modern capitalism (Viren and Vähämäki 2015). Universities are important producers of knowledge work, and as the critique of academic capitalism clearly shows, academia is irrevocably internalizing the values of neoliberalism as well.

In studies on university teachers (Jauhiainen, Jauhiainen and Laiho 2009; Jääskelä, Häkkinen and Rasku-Puttonen 2017), teachers draw attention to the paradoxical nature of teaching work. Although accountability has brought teaching new visibility, it is seen to have also led to the wrong type of competition and created barriers to cooperation between units. Teachers view teaching as a demerit and claim that putting much effort into developing teaching is a waste of time - even describing such efforts as 'academic suicide'. It is difficult for teachers to view their work as meaningful when all the incentives are focused on research. In addition, teachers do not necessarily get support by management to make time-consuming efforts to 
develop teaching. This is an ongoing discourse, typically justified as career development is almost exclusively determined by the number and quality of publications. Although we acknowledge this problematic situation, we think that by perpetuating this discourse, we would throw up our hands and give in to it. The attitude of 'blowing one's own horn' might be a good way to start a dialogue that promotes teaching as equally important within the scientific community. Undervaluing teaching means separating the horse and the carriage.

\section{Meaningful work as having, loving and being}

Meaningful work, however, is not only about personal perceptions and subjective volition but also about normative conditions (Ciulla 2000). Hence, meaningful work thus has both subjective and objective dimensions. To explore both dimensions, we apply Allardt's (1993) sociological theory of welfare. The model consists of three main conditions or categories: having, loving and being. These include both objective (needs) and subjective (individual wants) dimensions (see Table 1). In spite of the connotations to the hierarchy of needs they carry (Maslow 1943), Allardt's (1993) indicators can also be regarded as resources.

Insert Table 1 about here

The idea of meaningful work, with its subjective and objective dimensions and different levels (having, loving and being), is related to the idea of well-being at work, which 'refers to safe, healthy and productive work done by professional employees and working communities in organizations that are managed well' (Anttonen and Räsänen 2009, 18). Well-being at work is dependent on the physical, emotional and social factors inside and outside the organization 
and actual workplace (Buffet et al. 2013). Well-being at work also includes experiences of meaningfulness and rewarding so that work supports life management in general (Anttonen and Räsänen 2009).

Having refers to material conditions at work, such as the working space, education and measures of stress and work engagement. In the university context, material conditions include the physical campus environment, including the working environment. The learning environment is also part of universities' material conditions and includes features such as the curriculum, schedules and group sizes (see Konu and Rimpelä 2002). This category defines the basic level of well-being (Galtung 1975, 148). In Finland, which is the context of this study, the government defines the basic level of working conditions through labour legislation on employment contracts, working hours, annual holidays, non-discrimination, privacy rights and other issues (Ministry of Economic Affairs and Employment of Finland 2017). However, the environmental conditions in the university context can also comprise the resources, norms and standards that allow or restrict possibilities to fulfil one's duties and affect experiences of meaningful work. These elements include collaboration possibilities, teaching assessment, research and academic hierarchies, teaching and research aims and objects, and time resources for development (see Jauhiainen, Jauhiainen and Laiho 2009; Jääskelä et al. 2014; Jääskelä, Häkkinen and Rasku-Puttonen 2017).

Previous research shows that work characteristics, namely, job resources, have a special role in promoting well-being at work. Job resources are important for work engagement, which is positively linked with positive organizational outcomes, such as organizational commitment (Hakanen, Bakker and Schaufeli 2006; Hakanen, Schaufeli and Ahola 2008). In addition, high availability of job resources in a team is found to be related to team members' work engagement and perceived team performance (Mäkikangas et al. 2016). In sum, having consists of the 
material conditions at work, which form the foundation for well-being and meaningfulness at work.

Loving refers to social relationships, the need to relate to other people and build social identities. This occurs through contacts, dialogue, interaction, relationships and peer support with colleagues and other organization members. In the university context, social relationships include the social learning environment, team and group dynamics, cooperation, decisionmaking, atmosphere and relationships between and among students and teachers (Konu and Rimpelä 2002). The level of loving or social relationships does not necessarily correlate with the level of material level of well-being. In other words, social relationships can be rich in materially rich and poor communities as long as the material conditions remain sufficient. If the material conditions become poor, the stability, cohesiveness and harmony of relationships likely are also likely to deteriorate (Allardt 1993).

Since interaction is one of the main aspects of building conditions for loving or social relationships, attention should be paid to developing communication competence in organizations. Communication competence can be defined 'as an impression of appropriateness and effectiveness, which is functionally related to individual motivation, knowledge, skills, and contextual facilitators and constraints' (Spitzberg 2013, 126). Previous research has shown that emphasizing the role of communication competence helps organizations build ethical and responsible climate for communication (Hedman and Valkonen 2013; Hedman 2015), which can be seen as essential to loving. Collegial collaboration and support from both peers and management are recognized as crucial factors in the development of teaching at universities (Jääskelä, Häkkinen and Rasku-Puttonen 2017). Collegial support includes, for instance, the sharing of knowledge, experiences and expertise and a trusting atmosphere that allows for different viewpoints and perspectives. It is crucial that management encourages, supports and is engaged in teaching development (Jääskelä, Häkkinen and Rasku-Puttonen 2017). 
Being refers to the need for self-fulfilment and integration in society, including possibilities to participate, make decisions and have a meaningful work life. Allardt (1993) suggests that the category of being has both positive aspects (e.g. personal growth) and negative aspects (e.g. alienation). Consequently, it is important that individuals have opportunities to influence the main elements of their (working) life and to feel self-fulfilment (cf. Konu and Rimpelä 2002). In a university context, the experiences of self-fulfilment of both faculty and students are essential when examining the conditions of being. Faculty and students should be considered to be equal members of the university community, and both groups should be able to participate in making decisions that concern them. Furthermore, positive learning experiences, guidance, encouragement and respect facilitate self-fulfilment and maintenance of meaningfulness (Konu and Rimpelä 2002).

\section{Methods}

\section{Research context, material and analysis}

Previous research suggests that experiences of meaningfulness and job satisfaction depend on the specific work context and workplace requirements and priorities (Buffet et al. 2013). In this study, we are interested in experiences of meaningfulness in a university context. The research material was gathered from a management course at a business school in Finland. The business school is one of the faculties at one of Finland's largest multidisciplinary research universities, with six faculties and approximately 2,600 employees and 15,000 students. Since the institution's founding in 1863 as a Finnish-language teacher training college, dialogue among research, education and society has been a driving force in the university. With the multidisciplinary university established in 1966, it has aimed to balance research and education and has held open thinking as a core value. 
The driving force in the development of the studied course has been perceiving students not as objects of teaching but as subjects of their own learning and understanding. Regardless of roles, all the participants were co-learners. Allowing students to assume the role of coworkers through shared learning and course development emphasized, as Butler (1997) suggests, the holistic nature of people.

According to the applied idea of meaningful work, our research material consists of both objective and subjective indicators of meaningful work, including both lecturers' and students' experiences of meaningfulness. From the faculty members' perspectives, we used the lecturers' stories describing their experiences of cooperation, mutual learning and dialogue during the course. Research material on the students' perspectives was gathered at the end of the course with two questionnaires: the unstructured, anonymous, open course feedback form and the Agency of University Students (AUS) Scale (Jääskelä et al. 2017). The AUS questionnaire focused on the students' experiences of the interplay of resources for agency in the course context. The students used a 5 -point Likert scale $(1=$ fully disagree; $5=$ fully agree $)$ to assess their agency on 54 items.

In this study, we have concentrated especially on the students' assessments of their perceived personal, relational and participatory resources of agency, which are at the core of the AUS Scale (Jääskelä et al. 2017). Personal resources of agency consist of the students' experiences of their self-efficacy and competence beliefs, their interest and motivation in course, and the perceived utility value of the course. We see the AUS Scale items on personal resources and course satisfaction and dissatisfaction as relevant to the categories of having and being (see Allardt 1993). Relational resources of agency refer to the social relationships among the students and between the teachers and students: their experiences of trust, support and equal treatment among other students facilitated by the teachers and their experiences of peer support in the course. We see that the AUS Scale items on relational resources captures the category of 
loving (see Allardt 1993). Participatory resources of agency include the students' interpretations of access and possibilities to participate, influence and make choices in the course, in other words, the students' experiences of being in a community (see Allardt 1993).

Altogether, the study data comprised (1) three narratives written by the lecturers (nine pages of text); (2) qualitative student data consisting of anonymous, open course feedback from 37 students who attended the course in 2015 (response rate 50.7\%); and (3) quantitative student data, including agency ratings, from 64 students who attended the course in 2015 (response rate $87.6 \%$ ). Student data were drawn from a total of 73 students who attended the management course organized in 2015. Students' average age was 27 years (range: $21-48$ years); $71 \%$ were women and 29\% men. Students had multidisciplinary backgrounds, with majors in the university's five other faculties but not the business school. All students attending the course were studying management as a minor. In addition, student data were collected from a comparison group of 28 students who were majoring in business and attended an ordinary management course implemented in 2015 that did not focus on having, loving and being.

The lecturers wrote narratives on the same theme and title of 'Making work meaningful' and covered their individual experiences of meaningful work in a specific university course. We conducted a qualitative content analysis (Hsieh and Shannon 2005) to describe the central factors of meaningful work. The lecturers, also authors of this paper, wrote their narratives without reading the others', so they could not influence each other's thoughts. The data can be seen autoethnographic as these narratives demonstrate the researchers' own experiences trying to widen the understanding of meaningful work (Chang 2016). After all three lecturers wrote their narratives, we started the analysis by individually reading the narratives in turns to get a holistic picture of the data (c.f. Chang 2016). After this individual analysis, we met to conduct the final analysis as a group, performing collaborative autoethnography (Chang 2016). We utilised analytical-interpretive autoethnograpic writing (Chang 2016; Van Maanen 1988) as we 
applied Allardt's (1993) indicator system, giving special attention to both objective and subjective indicators in analysing the research material and evaluating and understanding the factors of meaningful work.

The students' open course feedback was also analysed using qualitative content analysis. The responses related to Allardt's (1993) categories were thematically classified and labelled. The students' responses to the AUS Scale were statistically analysed utilizing the results of the factor analyses (EFA and CFA) and the reliability analyses of the prior validation study (Jääskelä et al. 2017a). The mean scores of the following ten sum variables were utilized in the analysis: interest and utility value, self-efficacy, competence beliefs, trust, equal treatment, teacher support, peer support, participation activity (including ease of participation), opportunities to influence, and opportunities to make choices. Independent samples t tests were conducted to compare the students' assessment of their agency resources in the two study groups. Cohen's d (1988) was used to examine the effect sizes.

\section{Findings}

In this section, we focus on the three categories of meaningful work (having, loving and being) emphasized in our research material. These categories are summarized in Table 2 and discussed in-depth in this section. We present the findings on first the lecturers' and then the students' perceptions of having, loving and being. We use both students' open course feedback and agency ratings to illustrate the students' perceptions of having, loving and being. We see that these elements are also present in the students' assessments of their personal, relational and participatory resources of agency measured with the AUS Scale.

Insert Table 2 about here 


\section{Having}

\section{Lecturers' perceptions of having}

As described previously, having refers to the material conditions at work. In their narratives, the lecturers identified resources and facilities as important objective factors for meaningful work. First, the multidisciplinary course had varied enrolment involving participants with various knowledge bases from different faculties, which set certain conditions for teaching and learning in the course. Although coordinated by the business school, the course was organized through cooperation among different units in the university. The teachers described opportunities for interfaculty cooperation as an important resource. There were no administrative or organisational borders or restrictions on cooperation. This interdisciplinary cooperation was also found to support engagement in work. In addition, resources such as sufficient time and adequate, healthy working and teaching spaces were mentioned to support meaningfulness at work. Professional and pedagogical knowledge, collaborative networks and sharing of tasks were also viewed as part of having. Different types of knowledge and competences were found to give essential support for meaningfulness. The lecturers' pedagogical and communication competence and broad expertise and professional knowledge from multiple fields were found to support meaningfulness. The following excerpts highlight these aspects of having:

I think it is important that the administration and supervisors received our plans positively, and they did not limit the collaboration or set boundaries on it.

(Lecturer 3) 
Pedagogical knowledge and wide-ranging professional expertise are essential in making our collaboration meaningful. (Lecturer 2)

From the subjective perspective, having was described in willingness to collaborate, mutual interests in teaching and pedagogy, and experiences of sharing knowledge, tasks and responsibilities. The sharing of varied perspectives based on different educational, professional and individual backgrounds was found to be an essential part of the lecturers' collaboration. The diversity (e.g. education, professional background and age) of the teacher team was found to be a strength and supporting factor of meaningfulness. In the narratives, the lecturers noted that shared high engagement and commitment to the course enhanced their experiences of job satisfaction and work engagement. Collaboration in the course was experienced through mutual and shared learning when one knew that support was always available when needed. Collaboration was identified as a core factor in meaningfulness:

Collaboration among colleagues supported and maintained my experiences of meaningfulness at work in this course. .... Interaction and the zeal and will to work together have been important factors in our collaboration. (Lecturer 1)

First, I want to highlight the importance of sharing. Our starting point was that everybody shares materials, the knowledge related to the course and one's own professional expertise with others. This was the foundation for the course planning. This sharing made me feel that we all have our own special expertise that we respect. Everybody could feel recognized as a member of the group, which is essential in supporting self-esteem. (Lecturer 3) 


\section{Students' perceptions of having}

Similar to the lecturers, the students emphasized interfaculty cooperation, knowledge sharing, collegial support, varying pedagogical approaches to facilitating learning, and possibilities for peer collaboration as important resources. The students felt that in addition to the teachers' expertise, their peers from other faculties brought expertise to the group. In the anonymous open course feedback, the students also stressed the good, supportive working atmosphere as a motivating factor. The following excerpts from the students' open feedback responses highlight their perceptions on the category of having:

The lecturers had high expertise, and they were very supportive. The atmosphere was good, and it was nice to come to the lectures. I got the feeling that the course was deliberately planned to serve the students as well as possible. (Anonymous student 2015)

The discussions within the small group deepened my learning and helped me to understand the kind of knowledge I possessed - thanks to multidisciplinary small groups. It was rewarding to realize that certain issues that were clear to me were not at all clear to my peers from other faculties, and this helped me to identify my own knowledge. (Anonymous student 2015)

The students' satisfaction with the course was assessed using seven AUS Scale items capturing interest and motivation in the course and perceptions of its utility value. The students in both groups expressed medium levels of satisfaction with the course $(M=3.46$, multidisciplinary management course; $M=3.14$, comparison group) (Table 3 ). These results indicate that the students' experiences of interest, motivation and utility value were not fully 
realised in these two study groups. The results may also reflect that the students' interest was not necessarily dependent on the form of the course or the pedagogical approach applied. Various factors such as the course content, personal interest in the subject and even the conditions of studying could have influenced their assessments. However, based on the open course feedback, it can be speculated that the teachers' engagement and successful collaboration among themselves may have also affected the students' perceptions of the course.

Insert Table 3 about here

\section{Loving}

\section{Lecturers' perceptions of loving}

Loving refers to social relationships, or the need to relate to other people and build social identities. In their narratives, the lecturers discussed the importance of interaction, dialogue, communication and teamwork, which can be identified as objective aspects of social relationships.

Concerning the subjective aspects of loving (social relationships), the lecturers discussed trust as essential to supporting and maintaining meaningfulness. Constructive, genuine dialogue was found to be important to building trust within the teacher team. High peer support was also experienced as significant to social relationships. The lecturers noted that learning from and with others was important. Additionally, different forms of social support including asking for, receiving, observing and assessing support were discussed in the narratives. The lecturers noted that the group had a supportive working atmosphere, with no 
fear when discussing issues and giving feedback. Overall, a good team spirit provided experiences of meaningfulness in an atmosphere of cooperation and working together.

The lecturers described their personal relationships as deepening during the collaboration on the course. Getting to know each other made it easier to share thoughts and personal feelings. The good team spirit and enjoyment provided experiences of empowerment and joy. The lecturers described how they found it crucial to have opportunities to make their own decisions and influence their working practices. Moreover, collaboration and sharing of ideas, tasks and responsibilities enhanced their experiences of meaningfulness and well-being. One outcome of good social relationships was creativity. A good team offered possibilities to create something new that may not have emerged itself when working alone. This is highlighted in the following excerpt:

Working together and learning from and with others also feeds creativity. When one throws out an idea, another can continue with it, and a third further refines

it, so creativity becomes iterative. It is essential that we all feel that we are doing things for all of us. (Lecturer 3)

\section{Students' perceptions of loving}

The students' feedback also supported that building, maintaining and enhancing social relationships are important for creating meaningfulness at work. As expressed in the following excerpts, the students mentioned interaction, dialogue and teamwork as important to building meaningfulness during the course: 
I think the different perspectives on communication were a good addition to the course as the most important management tools are communication competence and the ability to face other humans. (Anonymous student 2015)

The teamwork and discussions in the team were the best part and enhanced learning. (Anonymous student 2015)

The teamwork was great but also challenging. The dialogical tasks during the lectures were good and helped me to analyze the issues taught. It was good that the groups were organized around students from different fields. (Anonymous student 2015)

This was also supported by the quantitative data. The students' assessments of the relational resources in the course showed that the students assessed their relational resources of agency as rather high (over four) in equal treatment, teacher support and trust. Only peer support was rated as medium level (Table 4).

Insert Table 4 about here

When comparing the results with the comparison group, it is worth noting that based on the $t$ test and effect sizes, there were statistically significant differences in the dimensions of teacher support $(p<.001$, Cohen's $d=0.81)$ and trust $(p<.001$, (Cohen's $d=0.89)$. Although the $t$ test gave some support for statistically significant differences in peer support $(p<.05)$, 
Cohen's $d$ remained rather low $(d=0.43)$. Based on these findings, the students attending the multidisciplinary management course felt higher support, especially from the teachers, and perceived the course climate as safer and more supportive than the students in the comparison group. For example, the students in the multidisciplinary course more often felt that the teachers could be easily approached and trusted and were interested in the students' viewpoints. These same elements are also seen as important in the loving category in Allardt's (1993) theory. The findings reflected that from the students' perspective, the climate in the course was safe and supported trust. To sum up, the students had rather positive perceptions of loving (e.g. collegial and teacher support, encouragement, trust and safety).

\section{Being}

\section{Lecturers' perceptions of being}

Being refers to the need for self-fulfilment and integration into society. The lecturers identified objective aspects of being (e.g. participation, meaning-making and personal growth) as essential for supporting meaningfulness at work. Furthermore, the importance of emotional support was discussed in the narratives. The lecturers also cited being heard as an essential factor in meaningfulness, as well as taking and sharing responsibility. The lecturers described shared values, aims and philosophical aspects (teaching philosophy) as enhancing experiences of meaningfulness, self-fulfilment, belongingness and integration into the team:

One factor that makes work on this course meaningful is that all three lecturers share similar interests in pedagogy and research. Our teaching philosophies match perfectly. ... In this teacher team, I get recognition as a pedagogue and as a person. (Lecturer 2) 
From the subjective perspective, being was identified with positive learning experiences and opportunities to exercise influence and participate in decision-making. Collaborative teaching enhanced lecturers' experiences of belongingness to both the team and the organization. In addition, factors such as respect and high self-esteem were discussed in the narratives to support meaningfulness. The following excerpt highlights the importance of shared values in providing meaningfulness at work:

Good cooperation requires some kind of shared values and similar views of modes and quality of cooperation. ... [For this course,] we started with shared value discussions before we really started to work together. Trust was built little by little within dialogue and in the actual work that was in line with our shared values. (Lecturer 3)

\section{Students' perceptions of being}

In the students' feedback, they appreciated reflection as means of individual growth and possibilities to integrate their own experiences with theories. The students also mentioned that the course assignment to create a personal plan for well-being was a good exercise, and wellbeing was widely discussed as a practical and theoretical concept. The following excerpts highlight the students' perceptions of being:

It was good that we had to do the personal plan for well-being. (Anonymous student 2015)

Good personal reflection and thinking were implemented during the course. Also, integrating theoretical issues with our own meaning-making and experiences was 
good. It was good that well-being at work was introduced from broad perspectives. Especially, emphasizing interaction and communication was very interesting from the perspective of a communication student. (Anonymous student 2015).

The students' assessments of their personal and participatory resources related to the being mode ranged from high and rather low. They evaluated their self-efficacy $(M=4.51)$ and competence beliefs $(\mathrm{M}=4.58)$ as high, but their participation activity $(\mathrm{M}=3.46)$ and opportunities to exercise influence $(M=3.34)$ as medium. Surprisingly, the students evaluated their opportunities to make choices (e.g. choosing between the working methods used in the course $)$ as especially low $(\mathrm{M}=1.45 ; \mathrm{SD}=0.68)$, though there was some variation among the responses (Table 5).

Insert Table 5 about here

The comparisons showed statistically significant differences between the groups in selfefficacy $(p<.05)$, suggesting that the students in the multidisciplinary management course experienced slightly more self-efficacy $(M=4.51 ; S D=0.48)$ than the students in the comparison group $(\mathrm{M}=4.28 ; \mathrm{SD}=0.57)$. However, the effect size remained low (Cohen's $\mathrm{d}=$ 0.44). To sum up, the students experienced both supporting and hindering elements of being. Their self-efficacy and competence beliefs were supported, but possibilities to make individual choices remained quite low and did not support their self-fulfilment. 


\section{Discussion}

The results suggest that interactive working methods, dialogue and sharing of ideas play key roles in perceptions of work as meaningful from the students' perspectives. The challenge, however, is still how to facilitate the students' participation in self-fulfilment and active agency during the course. The students valued possibilities to exercise influence, participate and make choices on their own, which can be supported by pedagogical practices to foster agency (Jääskelä et al. 2017a). Pedagogical practices that emphasize interaction, cooperation and dialogue promote positive feelings of satisfaction, social relations and personal growth - the dimensions of having, loving and being - essential for perceiving work as meaningful. However, the use of interactive working methods does not necessarily give students' strong experiences of participatory resources, such as opportunities to exercise influence. Pedagogical interventions that also explicate these various modes are needed.

Moreover, the findings show that shared and multidisciplinary learning is an essential resource in the lecturers' experiences of meaningful work in the university context. This finding deepens understanding of the role of collegial support in teaching development (Jääskelä, Häkkinen and Rasku-Puttonen 2017) and stresses the role of interdisciplinary expertise in pedagogical planning and teaching work. A positive, fulfilling state of mind - in other words, work engagement - is important for teachers' and students' experiences of meaningfulness, relevance and well-being at work (e.g. Hakanen, Bakker and Schaufeli 2006; Hakanen, Schaufeli and Ahola 2008). Based on the results of the present study, multidisciplinary pedagogical cooperation and dialogue promote new perspectives and foster positive experiences of work engagement; that is, they contribute to experiences of meaningful work among both students and lecturers. Sharing knowledge and resources, learning from others, enjoying pedagogical collegial support and exploring a variety of viewpoints develop, maintain 
and increase positive experiences of satisfaction, social relationships and self-fulfilment. In short, they contribute to experiences of meaningful work.

The factors causing individual work-related problems have long been understood to be not only subjective (e.g. Hakanen, Bakker and Schaufeli 2006; Hakanen, Schaufeli and Ahola 2008). However, without subjective engagement and effort, any arrangements to make an organization a good place to work fail to pay off. While the subjective factors in this study are at the forefront in understanding meaningful work, the framework applied also brings objective factors into the discussion. Our findings suggest that seemingly objective factors that may appear restrictive from an individual viewpoint, in fact, can be turned into positive resources with subjective involvement and efforts. Such objective factors include environmental conditions, such as the classroom size and number of students. Traditionally, students in socalled mass courses are treated as a single unit to whom the teacher lectures. As our case shows, however, interactive elements and dialogical learning are also possible within relatively large, varied groups. Seemingly restrictive factors thus can be turned into resources.

In organizational studies, the idea of meaningful work typically presupposes it is a good thing (Michaelson et al. 2014). We acknowledge its dark side and risks, such as negative performativity, time and other limited resources, increasing pressure for continuous course development, and the challenges caused by different values in life. However, in this study, we want to emphasize the positive side of meaningful work. Our experiences of collaboration have been empowering and fulfilling, as is evident in the summary of our findings.

As part of pedagogical professionalism, communication competence has played a significant role in our experiences of meaningful work. Equipping students with interpersonal communication competence is a central task in higher education (Hyvärinen et al. 2011, 291). We have emphasized communication and dialogue during the course and encouraged students to engage in such interactions by modelling constructive dialogue. 
We have also experienced positive attitudes and support at the institutional level while collaboratively developing and launching the course among different disciplines. Our experiences confirm Jääskelä, Häkkinen and Rasku-Puttonen’s (2017) finding that 'increasing interaction between the institutional levels can make educational development successful'. Contrary to the findings of Stenfors-Hayes et al. $(2010,404)$, the differences in positions and, in our case, generations was actually a benefit and resource for development and intellectual discussions. Jääskelä, Häkkinen and Rasku-Puttonen (2017, 14) emphasize development initiatives among groups, departments and faculties to share good practices and recommend building bridges among universities. Based on our experiences at the local level, we can only support such initiatives. However, without trust, willingness to share knowledge and respect for others' professionalism, collaboration between different parties is bound to fail.

We have experienced the academic freedom, shared social support and collaboration with inspirational colleagues Alpay and Verschoor $(2014,365)$ found so valuable. Alpay and Verschoor (2014) further observed that opportunities to use teaching to support research are often underutilized. Our study, therefore, can be regarded as a good example of turning collaborative developmental teaching into research, and we hope it encourages others to take the next step and initiate collaboration. Local collaboration can create a new culture of sharing and caring. As Jauhiainen, Jauhiainen and Laiho (2009) state, academic culture is the result of long historical development, but we can all influence that development by seeing and doing things anew. Many traditional (Humboldtian) academic values and ideals are still worthy of commitment, as Ylijoki and Ursin (2015) point out, but nothing hinders us from bringing new content and meanings to these values.

\section{Conclusion}


This study contributes to the discussion of meaningful work in a university context. As discussed above, both lecturers and students valued support, dialogue and the sharing of knowledge, which are all essential relational elements of meaningful work. Our study emphasized the role of subjective involvement and efforts to make work meaningful for both faculty and students. If we acknowledge the idea of learning as sharing and cooperating, then we must develop new ways for both parties to engage in collaboration. Both traditional academic principles and new approaches and perspectives are needed to support collaboration, sharing and other features of meaningful work. As academics, it is up to us to start the discussion and develop new interventions to reduce the divisions between research and teaching and to stop the undervaluation of the latter.

\section{References}

Alajoutsijärvi, K., Juusola, K., and Siltaoja, M. 2013. 'Academic Capitalism Hits the Fan: The Birth of Acamanic Capitalism'. In Dialogues in Critical Management Studies, edited by V. Malin, J. Murphy and M. Siltaoja, 91-121. UK: Emerald.

Allardt, E. 1993. 'Having, Loving, Being: An Alternative to the Swedish Model of Welfare Research'. In The Quality of Life, edited by A. Sen and M. C. Nussbaum, 88-95. Oxford: Oxford University Press.

Alpay, E., and Verschoor, R. 2014. 'The Teaching Researcher: Faculty Attitudes towards the Teaching and Research Roles'. European Journal of Engineering Education 39 (4): 365-376.

Anttonen, H., and Räsänen, T. (Eds.) (2009). Työhyvinvointi-uudistuksia ja hyviä käytäntöjä. Helsinki: Finnish Institute of Occupational Health. Retrieved from http://partner.ttl.fi/fi/verkkokirjat/Documents/BWW_ty\%C3\%B6hyvinvointi_web.pdf. 
Ball, S. J. 2003. 'The Teacher's Soul and the Terrors of Performativity'. Journal of Education Policy 18 (2): 215-228. doi:10.1080/0268093022000043065

Bennett, D. 2012. 'A Creative Approach to Exploring Student Identity’. International Journal of Creativity and Problem Solving 22 (1): 27-41.

Bowie, N. E. 1998. 'A Kantian Theory of Meaningful Work'. Journal of Business Ethics, 17 (9): 1083-1092.

Buffet, M. A., Gervais, R. L., Liddle, M., and Eechelaert, L. 2013. Well-Being at Work: Creating a Positive Work Environment. Luxembourg City: European Agency for Safety and Health at Work. https://osha.europa.eu/en/tools-andpublications/publications/literature_reviews/well-being-at-work-creating-a-positivework-environment/view.

Bunderson, J. S., and Thompson, J. A. 2009. 'The Call of the Wild: Zookeepers, Callings, and The Dual Edges of Deeply Meaningful Work'. Administrative Science Quarterly 54 (1): $32-57$.

Butler, J. 1997. The Psychic Life of Power: Theories in Subjection. Stanford, CA: Stanford University Press.

Cantwell, B., and Kauppinen, I., eds. 2014. Academic Capitalism in the Age of Globalization. Johns Hopkins University Press.

Chang, H. 2016. 'Individual and Collaborative Autoethnography as Method. A Social Scientist's Perspective'. In Handbook of Autoethnography, edited by S. H. Jones, T. E. Adams and C. Ellis, 107-122. New York: Routledge.

Ciulla, J. 2000. The Working Life: The Promise And Betrayal of Modern Work. New York: Three Rivers Press.

Ciulla, J. B. 2015. 'Meaningful Work'. Wiley Encyclopedia of Management 2, 1-3. doi:10.1002/9781118785317.weom020145. 
Cohen, J. (1988). Statistical Power Analysis for the Behavioral Sciences. 2nd ed. Hillsdale, NJ: Lawrence Earlbaum Associates.

Fotaki, M., and Prasad, A. 2015. 'Questioning Neoliberal Capitalism and Economic Inequality in Business Schools'. Academy of Management Learning and Education 14 (4): 556-575.

Fried, Y., and Ferris, G. R. 1987. 'The Validity of the Job Characteristics Model: A Review and Meta-Analysis'. Personnel Psychology 40 (2): 287-322.

Galtung, J. 1975. 'Measuring World Development I'. Alternatives 1 (1): 131-158.

Grant, A. M. 2008. 'The Significance of Task Significance: Job Performance Effects, Relational Mechanisms, and Boundary Conditions'. Journal of Applied Psychology 93 (1): 108-124.

Griffioen, D. M. E., Doppenberg, J. J., and Oostdam, R. J. 2018. 'Are More Able Students in Higher Education Less Easy To Satisfy?'. Higher Education 75 (5): 891-907. doi:10.1007/s10734-017-0176-3.

Hakanen, J. J., Bakker, A. B., and Schaufeli, W. B. 2006. 'Burnout and Work Engagement among Teachers'. Journal of School Psychology 43 (6): 495-513.

Hakanen, J., Schaufeli, W., and Ahola, K. 2008. 'The Job Demands-Resources Model: A Three-Year Cross-lagged Study of Burnout, Depression, Commitment, and Work Engagement'. Work \& Stress 22 (3): 224-241. doi:10.1080/02678370802379432.

Hedman, E. 2015. Facilitating Leadership Team Communication. Jyväskylä Studies in Humanities 266. Jyväskylä, Finland: University of Jyväskylä. http://urn.fi/URN:ISBN:978-951-39-6390-3.

Hedman, E., and Valkonen, T. 2013. 'Vuorovaikutusosaamisen relationaalisuus ja työyhteisön kehittäminen'. In Työelämän tutkimuspäivät 2012. Suomella töissä? Kestämistä ja kestävyyttä, edited by M. Virkajärvi, 1-13. Työelämän tutkimuspäivien 
konferenssijulkaisuja, 4/2013. Tampere, Finland: Tampereen Yliopisto.

http://urn.fi/URN:ISBN:978-951-44-9063-7.

Hsieh, H-F., and Shannon, S. E. 2005. 'Three Approaches to Qualitative Content Analysis'. Qualitative Health Research 15 (9): 1277-1288.

Hsieh, N. H. 2008. 'Survey Article: Justice in Production'. Journal of Political Philosophy 16 (1): $72-100$.

Hyvärinen, M. L., Tanskanen, P., Katajavuori, N., and Isotalus, P. 2012. 'Evaluating the Use of Criteria of Assessing Profession-Specific Communication Skills in Pharmacy'. Studies in Higher Education 37 (3): 291-308.

Jauhiainen, A., Jauhiainen, A., and Laiho, A. 2009. 'The Dilemmas of the "Efficiency University” Policy and the Everyday Life of University Teachers'. Teaching in Higher Education 14 (4): 417-428.

Jääskelä, P., Häkkinen, P., and Rasku-Puttonen, H. 2017. 'Supporting and Constraining Factors in the Development of University Teaching Experienced by Teachers'. Teaching in Higher Education 22 (6): 655-671.

Jääskelä, P., Poikkeus, A-M., Vasalampi, K., Valleala, U-M., and Rasku-Puttonen, H. 2017. 'Assessing Agency of University Students: Validation of the Agency of University Students Scale'. Studies in Higher Education 42 (11): 2061-2079. doi:10.1080/03075079.2015.1130693.

Jääskelä, P., Vesisenaho, M., Rasku-Puttonen, H., and Häkkinen, P. 2014. 'Interaction and eEducation: What Kind of Support Is Needed To Develop University Teaching?’ In ICERI2014 Proceedings, edited by L. Chova, A. Martínez and I. Torres, 5150-5159. IATED Academy.

Lepisto, D. A., and Pratt, M. G. 2017. 'Meaningful Work as Realization and Justification: Toward a Dual Conceptualization'. Organizational Psychology Review 72 (2), 99-121. 
Kenny, J. 2017. ‘Academic Work and Performativity'. Higher Education 74 (5): 897-913.

King, L. A., and Napa, C. K. 1998. 'What Makes a Life Good?'. Journal of Personality and Social Psychology 75 (1): 156-165.

Konu, A., and Rimpelä, M. 2002. 'Well-being in Schools: A Conceptual Model'. Health Promotion International 17 (1): 79-87.

Lancaster, L. C., and Stillman, D. 2010. The Mindfactor: How the Millennial Generation Is Rocking the Workplace. New York: HarperCollins.

Liden, R. C., Wayne, S. J., and Sparrowe, R. T. 2000. 'An Examination of the Mediating Role of Psychological Empowerment on the Relations between the Job, Interpersonal Relationships, and Work Outcomes'. Journal of Applied Psychology 85 (3): 407-416.

Maslow, A. H. 1943. 'A Theory of Human Motivation'. Psychological Review 50 (4): 370396.

May, D. R., Gilson, R. L., and Harter, L. M. 2004. 'The Psychological Conditions of Meaningfulness, Safety and Availability and the Engagement of the Human Spirit at Work'. Journal of Occupational and Organizational Psychology 77 (1): 11-37.

Michaelson, C., Pratt, M. G., Grant, A. M., and Dunn, C. P. 2014. 'Meaningful Work: Connecting Business Ethics and Organization Studies'. Journal of Business Ethics 121 (1): 77-90.

Ministry of Economic Affairs and Employment of Finland. 2017. 'Labour Legislation'. http://tem.fi/en/labour-legislation.

Mitra, R., and Buzzanell, P. 2017. 'Communicative Tensions of Meaningful Work: The Case of Sustainability Practitioners'. Human Relations 70 (5): 594-616.

Mäkikangas, A., Aunola, K., Seppälä, P., and Hakanen, J. 2016. 'Work Engagement-Team Performance Relationship: Shared Job Crafting as a Moderator'. Journal of Occupational and Organizational Psychology 89 (4): 772-790. 
Podolny, J. M., Khurana, R., and Hill-Popper, M. 2005. 'Revisiting the Meaning of Leadership'. Research in Organizational Behavior 26, 1-36.

Pratt, M. G., and Ashforth, B. E. 2003. 'Fostering Meaningfulness in Working and at Work'. In Positive Organizational Scholarship: Foundations of a New Discipline, edited by K. Cameron, J. E. Dutton and R. E. Quinn, 308-327. San Francisco: Berrett-Koehler.

Rosso, B. D., Dekas, K. H., and Wrzesniewski, A. 2010. 'On the Meaning of Work: A Theoretical Integration and Review'. Research in Organizational Behavior 30, 91-127.

Schwartz, A. 1982. 'Meaningful Work'. Ethics 92 (4): 634-646.

Soane, E., Shantz, A., Alfes, K., Truss, C., Rees, C., and Gatenby, M. 2013. 'The Association of Meaningfulness, Well-Being, and Engagement with Absenteeism: A Moderated Mediation Model'. Human Resource Management 52 (3): 441-456.

Spitzberg, B. H. 2013. '(Re)Introducing Communication Competence to the Health Professions'. Journal of Public Health Research 2 (3): 126-135.

Stenfors-Hayes, T., Weurlander, M., Owe Dahlgren, L., and Hult, H. 2010. 'Medical Teachers’ Professional Development—Perceived Barriers and Opportunities'. Teaching in Higher Education 15 (4): 399-408.

Van Maanen, J. 1988. Tales of the Field: On Writing Ethnography. Chicago: University of Chicago Press.

Viren, E., and Vähämäki, J. 2015. Seutu joka ei ole paikka. Kapitalismi ja metropoli. Helsinki: Tutkijaliitto.

Wardley, L. J., Bélanger, C. H., and Nadeau, J. 2017. 'A Co-creation Shift in Learning Management: Work Design for Institutional Commitment and Personal Growth'. Higher Education 74 (6): 997-1013. 
Wrzesniewski, A., McCauley, C., Rozin, P., and Schwartz, B. 1997. 'Jobs, Careers, and Callings: People's Relations to Their Work'. Journal of Research in Personality 31 (1): $21-33$.

Yeoman, R. 2014. 'Conceptualising Meaningful Work as a Fundamental Human Need'. Journal of Business Ethics 125 (2): 235-251.

Ylijoki, O., and Ursin, J. 2015. 'High-flyers and Underdogs: The Polarisation of Finnish Academic Identities'. In Academic Identities in Higher Education: The Changing European Landscape, edited by L. Evans and J. Nixon, 187-202. Bloomsbury Academic. 
TABLE 1 Allardt's indicator system: having, loving and being cross-tabulated with objectivity and subjectivity (applied from Allardt, 1993, p. 93)

\begin{tabular}{|l|l|l|}
\hline & \multicolumn{1}{|c|}{ Objective aspect } & \multicolumn{1}{|c|}{ Subjective aspect } \\
\hline $\begin{array}{l}\text { Having } \\
\text { (material conditions) }\end{array}$ & $\begin{array}{l}\text { Objective measures of } \\
\text { the level of living and } \\
\text { environmental } \\
\text { conditions }\end{array}$ & $\begin{array}{l}\text { Subjective feelings of } \\
\text { satisfaction/dissatisfaction } \\
\text { with living conditions }\end{array}$ \\
\hline $\begin{array}{l}\text { Loving } \\
\text { (social relationships) }\end{array}$ & $\begin{array}{l}\text { Objective measures of } \\
\text { relationships to other } \\
\text { people }\end{array}$ & $\begin{array}{l}\text { Happiness/unhappiness - } \\
\text { subjective feelings about } \\
\text { social relations }\end{array}$ \\
\hline $\begin{array}{l}\text { Being } \\
\text { (self-fulfilment) }\end{array}$ & $\begin{array}{l}\text { Objective measures of } \\
\text { people's relation to } \\
\text { society }\end{array}$ & $\begin{array}{l}\text { Subjective feelings of } \\
\text { personal growth/alienation }\end{array}$ \\
\hline
\end{tabular}


TABLE 2 Summary of the findings

\begin{tabular}{|c|c|c|}
\hline & Objective aspect & Subjective aspect \\
\hline $\begin{array}{l}\text { Having } \\
\text { (material conditions: level of } \\
\text { living and environmental } \\
\text { conditions) }\end{array}$ & $\begin{array}{l}\text { Resources: time, space, } \\
\text { materials, professional } \\
\text { knowledge, instrumental } \\
\text { support, faculty support and } \\
\text { cooperation, sharing of tasks } \\
\text { and collaborative networks } \\
\text { - Knowledge and competence: } \\
\text { professional and pedagogical } \\
\text { knowledge, informational } \\
\text { support }\end{array}$ & $\begin{array}{l}\text { - Sharing: knowledge } \\
\text { sharing, shared interest in } \\
\text { and willingness to } \\
\text { collaborate, variety of } \\
\text { perspectives, tasks and } \\
\text { responsibilities } \\
\text { - Diversity as a strength } \\
\text { - High engagement and } \\
\text { commitment } \\
\text { - High peer support } \\
\text { - Mutual learning }\end{array}$ \\
\hline $\begin{array}{l}\text { Loving } \\
\text { (social relationships) }\end{array}$ & $\begin{array}{l}\text { - Dialogue } \\
\text { - Interaction } \\
\text { - Team work } \\
\text { - Emotional support } \\
\text { - Communication competence } \\
\text { - Student feedback }\end{array}$ & $\begin{array}{l}\text { - Trust: receiving feedback } \\
\text { and critique without fear } \\
\text { - High peer support } \\
\text { - Good team spirit: } \\
\text { cooperation and doing it } \\
\text { (working) together, joy, } \\
\text { 'one for all, and all for } \\
\text { one' } \\
\text { - Sharing of thoughts and } \\
\text { personal feelings } \\
\text { - Empowerment } \\
\text { - Creativity }\end{array}$ \\
\hline $\begin{array}{l}\text { Being } \\
\text { (self-fulfilment) }\end{array}$ & $\begin{array}{l}\text { - Participation } \\
\text { - Meaning-making } \\
\text { - Personal growth } \\
\text { - Emotional support }\end{array}$ & $\begin{array}{l}\text { - Positive learning } \\
\text { experiences } \\
\text { - High peer support } \\
\text { - Possibilities to participate } \\
\text { in decision-making and } \\
\text { exercise influence } \\
\text { - Experiences of } \\
\text { belongingness and respect: } \\
\text { doing the right things and } \\
\text { doing things right }\end{array}$ \\
\hline
\end{tabular}


TABLE 3 Students' perceived interest and utility value (cf. the having aspect of Allardt's theory)

\begin{tabular}{|l|c|c|c|c|c|c|c|c|}
\hline $\begin{array}{l}\text { Dimensions of } \\
\text { agency in the } \\
\text { AUS Scale }\end{array}$ & $\begin{array}{l}\text { Multidisciplina } \\
\text { ry management } \\
\text { course (n=64) }\end{array}$ & \multicolumn{2}{|c|}{$\begin{array}{l}\text { Comparison } \\
\text { group (n=28) }\end{array}$} & \multicolumn{4}{|c|}{ Test statistics } \\
\cline { 2 - 9 } & $M$ & $S D$ & $M$ & $S D$ & $t$ & $d f$ & $p$ & $\begin{array}{l}\text { Cohen's } \\
d\end{array}$ \\
\hline $\begin{array}{l}\text { Interest and } \\
\text { utility value }\end{array}$ & 3.46 & 0.73 & 3.14 & 0.86 & 1.83 & 90 & .070 & 0.40 \\
& & & & & & & & \\
\hline
\end{tabular}

Note. Rating scale 1-5: $1=$ low resources of agency; $5=$ high resources of agency 
TABLE 4 Students' perceived relational resources of agency (cf. the loving aspect of Allardt's theory, e.g. social relationships)

\begin{tabular}{|l|c|c|c|c|c|c|c|c|}
\hline $\begin{array}{l}\text { Dimensions of } \\
\text { relational } \\
\text { resources of } \\
\text { agency in the } \\
\text { AUS Scale }\end{array}$ & \multicolumn{2}{|l|}{$\begin{array}{l}\text { Multidisciplina } \\
\text { ry management } \\
\text { course (n=64) }\end{array}$} & \multicolumn{2}{|c|}{$\begin{array}{l}\text { Comparison } \\
\text { group (n=28) }\end{array}$} & \multicolumn{4}{|c|}{ Test statistics } \\
\cline { 2 - 9 } & $M$ & $S D$ & $M$ & $S D$ & $t$ & $d f$ & $p$ & $\begin{array}{l}\text { Cohen's } \\
d\end{array}$ \\
\hline $\begin{array}{l}\text { Equal } \\
\text { treatment }\end{array}$ & 4.30 & 0.78 & 4.25 & 0.75 & 0.31 & 90 & .756 & 0.07 \\
\hline $\begin{array}{l}\text { Teacher } \\
\text { support }\end{array}$ & 4.68 & 0.49 & 4.26 & 0.54 & 3.66 & 90 & .000 & 0.81 \\
\hline Peer support & 3.47 & 0.76 & 3.10 & 0.95 & 2.03 & 90 & .045 & 0.43 \\
\hline Trust & 4.49 & 0.48 & 4.01 & 0.59 & 4.12 & 90 & .000 & 0.89 \\
\hline
\end{tabular}

Note. Rating scale 1-5: $1=$ low resources of agency; $5=$ high resources of agency 
TABLE 5 Students' perceived personal and participatory resources of agency (cf. the being aspect of Allardt's theory, e.g. personal growth, self-fulfilment and involvement in decision making)

\begin{tabular}{|c|c|c|c|c|c|c|c|c|}
\hline \multirow{2}{*}{$\begin{array}{l}\text { Dimensions of } \\
\text { personal and } \\
\text { participatory } \\
\text { resources of } \\
\text { agency in the } \\
\text { AUS Scale }\end{array}$} & \multicolumn{2}{|c|}{$\begin{array}{l}\text { Multidisciplina } \\
\text { ry management } \\
\text { course }(n=64)\end{array}$} & \multicolumn{2}{|c|}{$\begin{array}{l}\text { Comparison } \\
\text { group }(\mathrm{n}=28)\end{array}$} & \multicolumn{4}{|c|}{ Test statistics } \\
\hline & $M$ & $S D$ & $M$ & $S D$ & $t$ & $d f$ & $p$ & $\begin{array}{l}\text { Cohen's } \\
d\end{array}$ \\
\hline \multicolumn{9}{|c|}{$\begin{array}{l}\text { Personal resources for agency (cf. the being aspect of Allardt's theory, e.g. personal growth } \\
\text { and self-fulfilment) }\end{array}$} \\
\hline Self-efficacy & 4.51 & 0.48 & 4.28 & 0.57 & 2.02 & 90 & .047 & 0.44 \\
\hline $\begin{array}{l}\text { Competence } \\
\text { beliefs }\end{array}$ & 4.58 & 0.45 & 4.56 & 0.39 & 0.22 & 90 & .827 & 0.05 \\
\hline $\begin{array}{l}\text { Participation } \\
\text { activity }\end{array}$ & 3.46 & 0.73 & 3.14 & 0.86 & 1.83 & 90 & .070 & 0.40 \\
\hline \multicolumn{9}{|c|}{$\begin{array}{l}\text { Participatory resources of agency (cf. the being aspect of Allardt's theory, e.g. involvement in } \\
\text { decision making) }\end{array}$} \\
\hline $\begin{array}{l}\text { Opportunities } \\
\text { to exercise } \\
\text { influence }\end{array}$ & 3.34 & 0.62 & 3.13 & 0.76 & 1.41 & 90 & .162 & 0.30 \\
\hline $\begin{array}{l}\text { Opportunities } \\
\text { to make } \\
\text { choices }\end{array}$ & 1.45 & 0.68 & 1.71 & 0.66 & 1.76 & 90 & .081 & -0.39 \\
\hline
\end{tabular}

Note. Rating scale 1-5: $1=$ low resources of agency; $5=$ high resources of agency 